\title{
Occurrence of Carangid FIsh Uraspis helvola (Forster, 1801) from the Iraqi Marine Waters, Arabian Gulf
}

\author{
Abdul-Razak M. Mohamed ${ }^{1,}$, Abbas J. Al-Faisal ${ }^{2}$ and Talib A. Jaayid ${ }^{3}$ \\ ${ }^{1}$ Department of Fisheries and Marine Resources, College of Agriculture, University of Basrah, Iraq \\ ${ }^{2}$ Marine Science Centre, University of Basrah, Iraq \\ Email: abbas_jsm@yahoo.com \\ ${ }^{3}$ Department of Animal Production, College of Agriculture, Basrah University, Iraq. \\ Email: taleb1968@yahoo.com \\ *Corresponding author's email: abdul19532001 [AT] yahoo.com
}

\begin{abstract}
The white tongue jack, Uraspis helvola (Forster, 1801) was recorded for the first time in the Iraqi marine waters, northwest Arabian Gulf. The samples were collected during the period from January 2014 to June 2015. U. helvola differed from other carangid fish species by tongue, roof and floor of mouth are white to yellowish and other parts are dark, and the anal fin spines embedded. Gill rakers ranged from four to five on upper limb and 12 to 13 on lower limb of first gill arch. The DNA fingerprint was identified of $U$. helvola by using Polymerase Chain Reaction-Random Amplified Polymorphic DNA (PCR-RAPD) with six primers: P1 (212), P2 (239), P3 (244), P4 (250), P5 (265), and P6 (347). The number of bands generated by primers was 51 and the size of bands ranged from 110 to $1440 \mathrm{bp}$.
\end{abstract}

Keywords-- Carangid fish, white tongue jack, morphology, DNA fingerprint, Iraq

\section{INTRODUCTION}

The family Carangidae (Perciformes) forms one of the largest families of bony fishes, there are 146 species belong to 30 genera distribution widely in the world [1]. Carangid fish can be distinguished from other teleost groups by the presence of detached anal spines, lateral line scutes, cutaneous fleshy lateral keels, two dorsal fins are separate, the first moderate height or very low with four to eight spines, caudal fin forked with the lobes equal in most species, dorsal and ventral grooves on caudal peduncle, adipose eyelids [2].

The genus Uraspis Bleeker, 1855 is characterized by the presence of a white tongue and embedded anal fin spines. This genus is composed of three species including U. helvola, U. secunda, and U. uraspis [3].

U. helvola is widely distributed in the Indo-West Pacific but rarely collected, confirmed records are from the Red Sea, Arabian Sea, off Oman and Sri Lanka and Hawaii [4], also known from the Arabian Gulf [5, 6, 7].

In this study, $U$. helvola as new present in the Iraqi marine waters is described by morphological characteristics and DNA fingerprint by using PCR-RAPD technique.

\section{MATERIALS AND METHOD}

The specimens of carangid fish (include two specimens of $U$. helvola) were collected from the Iraqi marine waters $\left(29^{\circ} 46^{\prime} 50^{\prime \prime} \mathrm{N} 48^{\circ} 39^{\prime} 46^{\prime \prime} \mathrm{E}\right.$ to $\left.29^{\circ} 78^{\prime} 83^{\prime \prime} \mathrm{N} 48^{\circ} 75^{\prime} 78^{\prime \prime} \mathrm{E}\right)$ by using trawl net, and from commercial fishery in Al-Faw fish landings, $100 \mathrm{~km}$ south of Basrah city, northwestern Arabian Gulf (Fig. 1), during the period from January 2014 to June 2015. Eight meristic characters were counted employing dissection microscope and twenty morphometric characters were measured to the nearest $\mathrm{mm}$ by fish measuring board and digital vernier following [6]. The specimens are deposited in the collection of the Fish Museum of the Marine Science Centre, University of Basrah, Iraq. 


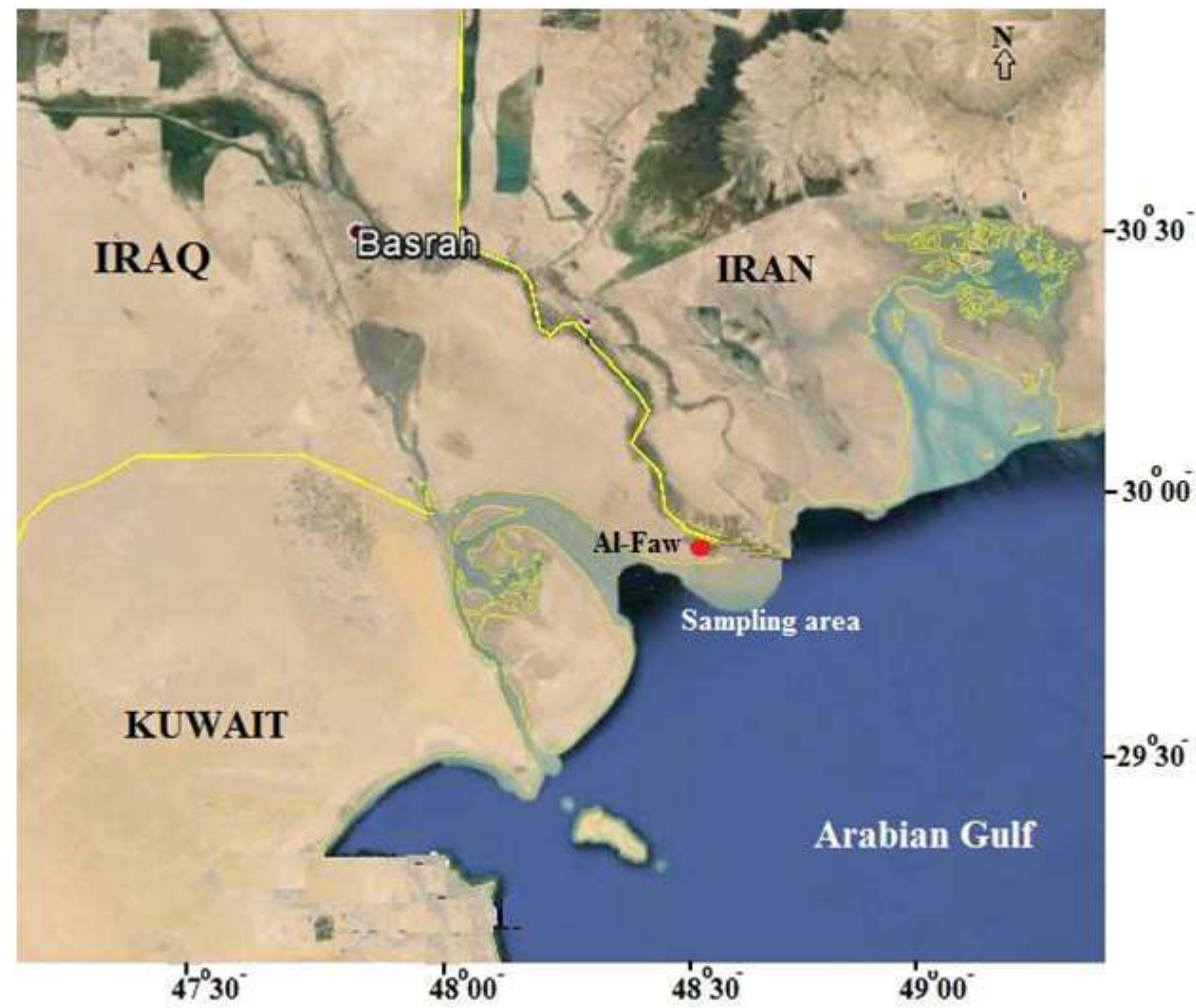

Figure 1: Map elucidating sampling locations from the Iraqi marine waters.

Genomic DNA was extracted from $20 \mathrm{mg}$ of muscle tissues of the species, according to Invitrogen kit instructions (Pure linkgenomic DNA kit, USA). Six primers were used in PCR-RAPD technique which were as follow: P1 (212): GCT GCG TGA C, P2 (239): CTG AAG CGG A, P3 (244): CAG CCA ACC G,P4 (250): CGA CAG TCC C, P5 (265): CAG CTG TTC A and P6 (347): TTG CTT GGC G (Murakami et al. 2007). PCR was performed in a total volume of 25 $\mu \mathrm{L}$, containing $12.5 \mu \mathrm{L}$ master mix, $2 \mu \mathrm{L}$ primer, $3 \mu \mathrm{L}$ genomic DNA, $7.5 \mu \mathrm{L}$ distilled water. PCR cycling conditions were $94^{\circ} \mathrm{C}, 1.5 \mathrm{~min}$ for initial denaturation, then 40 cycles of $38^{\circ} \mathrm{C}, 2 \mathrm{~min}, 72^{\circ} \mathrm{C}, 2 \mathrm{~min}, 91^{\circ} \mathrm{C}, 1 \mathrm{~min}$. An additional step of $72^{\circ} \mathrm{C}(5 \mathrm{~min})$ was performed for final extension. Amplification products were analyzed by $1.5 \%$ agarose gels electrophoresis ( $80 \mathrm{~V}$ and $50 \mathrm{~min}$ ) and staining with ethidium bromide. The samples migrated with the $100 \mathrm{bp}$ ladder. Gel profile was checked by UV transilluminator and photographs were taken by Photonyx S 140 direct copy system (NyxTechnik Company, USA).

The RAPD product of $U$. helvola and five species of carangid fish (Alepes djedaba, A. kleinii, A. vari, Seriolinanigro fasciata and Trachinotus mookalee) were compared. The genetic similarity (GS) between the species was computed based on pair comparison between them for primers using the following formula [8]:

$$
\mathrm{GSxy}=2 \mathrm{Nxy} /(\mathrm{Nx}+\mathrm{Ny})
$$

where, Nx and Ny were the number of bands in individuals X and Y. Nxy was the number of shared bands. The similarity values were converted into genetic distance using the formula: $D=1$ - GS.

\title{
3. RESULTS
}

U. helvola (Fig. 2) was recorded for the first time in the Iraqi marine waters, which belong to the following classification section:

\author{
Class: Actinopterygii \\ Order: Perciformes \\ Family: Carangidae \\ Genus: Uraspis (Bleeker, 1855)
}

Species: U. helvola (Forster, 1801)

Scomber helvolus Forster, 1801

Caranx helvolus Cuvier and Valenciennes, 1833

Uraspis helvolaWilliams, 1961 


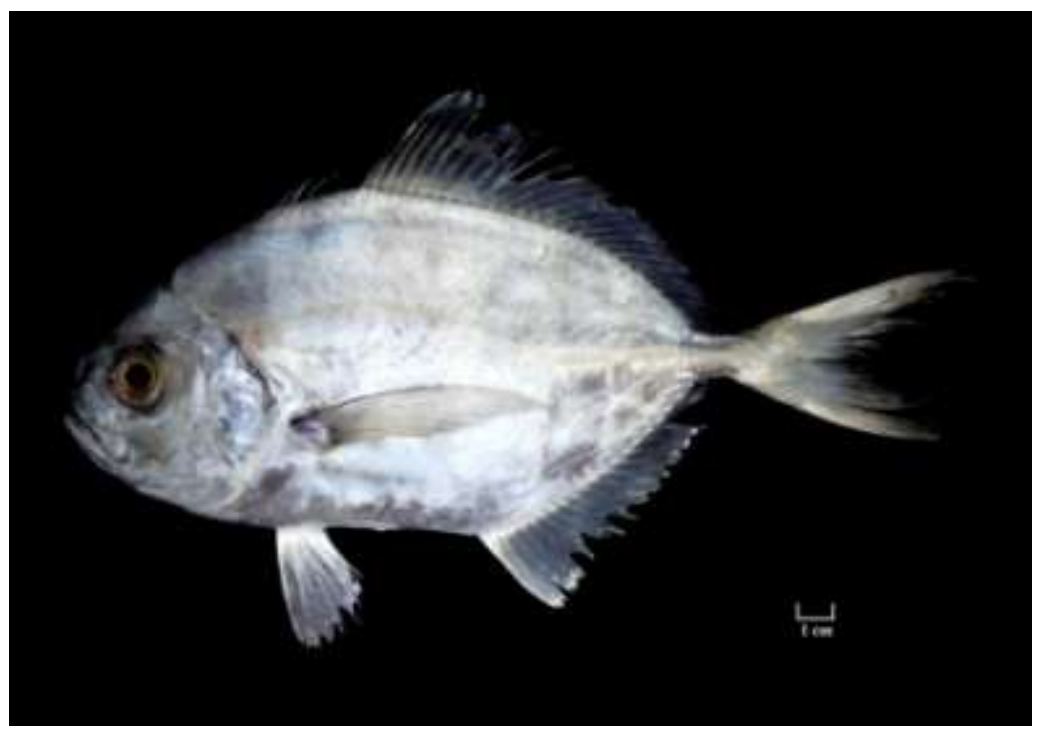

\subsection{Morphological description}

Figure 2: U. helvola from the Iraqi marine waters.

Tables ( 1 and 2) show the morphometric and meristic characteristics of $U$. helvola, body oblong $50.35-52.29 \%$ in standard length and compressed $13.93-15.51 \%$, dorsal profile strongly convex, ventral profile slightly convex to isthmus. Teeth in both jaws are small. Snout length ranged from 11.94 to $12.53 \%$. Eye diameter ranged from 8.51 to $8.71 \%$. Gill rakers ranged from four to five on upper limb and 12 to 13 on lower limb of first gill arch. Two dorsal fins, the first with eight spines, followed 27 rays, anal fin with two embedded detached spines followed by 21 rays. Total vertebrae are 23 (Fig. 3). Color of tongue, roof and floor of mouth are white, the rest blue-black, head dusky to black, body dusky to black dorsally, lighter below and with wide, dark bands and narrow pale interspaces.

Table 1: Morphometric characters of $U$. helvola from the Iraqi marine waters.

\begin{tabular}{lccc}
\hline Morphometric characters & Range & Mean & SD \\
\hline Total length (mm) & $233.0-245.0$ & 239.0 & 8.49 \\
Fork length (mm) & $200.0-210.0$ & 205.0 & 7.07 \\
Standard length (mm) & $168.0-178.0$ & 173.0 & 7.07 \\
Body depth \% in SL & $50.35-52.29$ & 51.32 & 1.37 \\
Body width \% in SL & $13.93-15.51$ & 14.72 & 1.11 \\
Head length \% in SL & $33.65-35.44$ & 34.54 & 1.27 \\
Head depth \% in SL & $36.17-37.98$ & 37.08 & 1.28 \\
Head width \% in SL & $15.57-15.74$ & 15.65 & 0.12 \\
Snout length \% in SL & $11.94-12.53$ & 12.24 & 0.41 \\
Eye diameter \% in SL & $8.51-8.71$ & 8.61 & 0.14 \\
Interorbital distance \% in SL & $9.95-11.01$ & 10.48 & 0.75 \\
Predorsal length \% in SL & $34.11-35.84$ & 34.97 & 1.23 \\
Postdorsal length \% in SL & $6.29-6.60$ & 6.44 & 0.21 \\
$1^{\text {st Dorsal fin length \% in SL }}$ & $12.24-12.65$ & 12.45 & 0.29 \\
$2^{\text {nd }}$ Dorsal fin length \% in SL & $52.96-54.01$ & 53.48 & 0.74 \\
Anal fin length \% in SL & $35.16-41.54$ & 38.35 & 4.51 \\
Pectoral fin length \% in SL & $36.53-39.41$ & 37.97 & 2.04 \\
Pelvic fin length \% in SL & $19.79-22.17$ & 20.98 & 1.69 \\
Caudal peduncle length \% in SL & $7.01-8.24$ & 7.63 & 0.87 \\
Caudal peduncle depth \% in SL & $5.52-5.99$ & 5.76 & 0.34 \\
\hline
\end{tabular}


Table 2: Meristic characters of U.helvolafrom the Iraqi marine waters.

\begin{tabular}{|c|c|c|c|c|}
\hline \multicolumn{2}{|c|}{ Meristic characters } & Range & Mean & SD \\
\hline \multicolumn{2}{|c|}{ 1st Dorsal fin spines } & $8-8$ & 8 & 0 \\
\hline \multicolumn{2}{|c|}{ 2nd Dorsal fin rays } & $27-27$ & 27 & 0 \\
\hline \multirow[t]{2}{*}{ Anal fin } & spines & $2-2$ & 2 & 0 \\
\hline & rays & $21-21$ & 21 & 0 \\
\hline \multicolumn{2}{|c|}{ Pectoral fin rays } & $22-23$ & 22.5 & 0.71 \\
\hline \multicolumn{2}{|c|}{ Pelvic fin rays } & $5-6$ & 5.5 & 0.71 \\
\hline \multirow[t]{2}{*}{ Gill rakers } & upper limb & $4-5$ & 4.5 & 0.71 \\
\hline & lower limb & $12-13$ & 12.5 & 0.71 \\
\hline Vertebrae & & $23-23$ & 23 & 0 \\
\hline
\end{tabular}

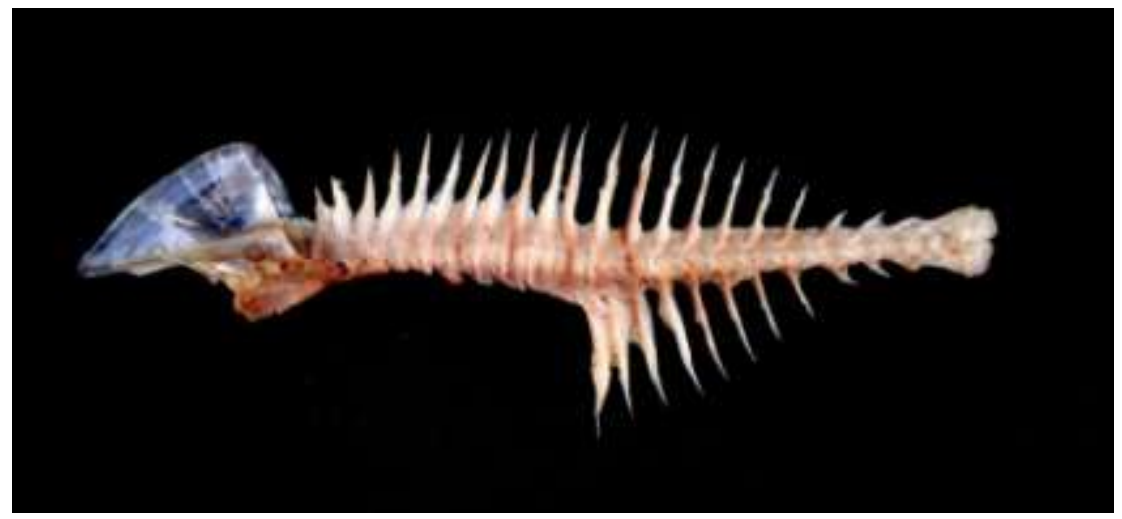

\subsection{DNA fingerprint}

Figure 3: Vertebral column of U. helvola.

The DNA fingerprint was identified of $U$. helvola using Polymerase Chain Reaction-Random Amplified Polymorphic DNA (PCR-RAPD). In this study, six primers were selected to identify species showed evident banding patterns and distinguishable differences between $U$. helvola and five species of carangid fish (Fig. 4). The number of bands generated was 51 in $U$. helvola, size of bands ranged from 110 to $1440 \mathrm{bp}$. The genetic similarity was 0.29 with $A$. djedaba, 0.25 with $A$. kleinii, 0.24 with $A$. vari, 0.23 with $S$. nigrofasciata and 0.36 with $T$. mookalee while the genetic distance among them were $0.70,0.74,0.76,0.76$ and 0.63 , respectively.
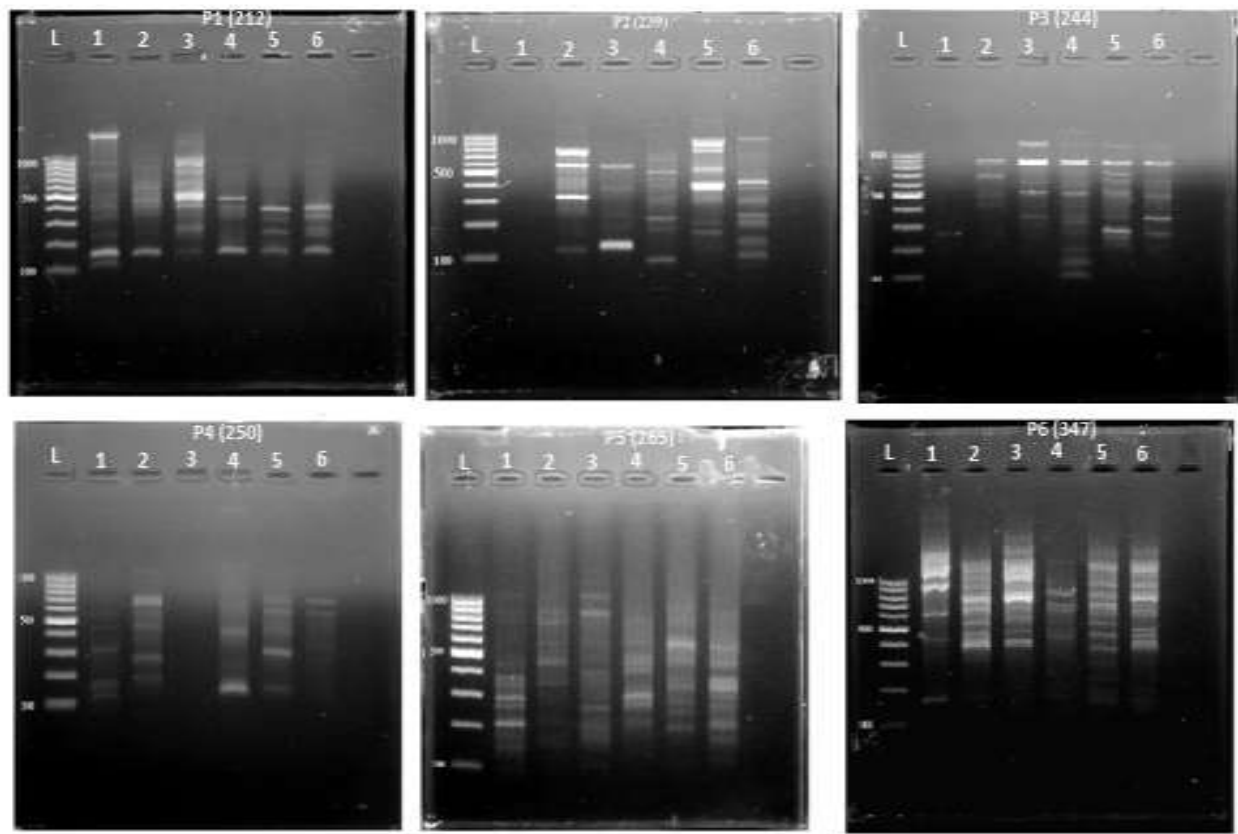

Figure 4: PCR-RAPD products using P1 (212), P2 (239), P3 (244), P4 (250), P5 (265), and P6 (347) primers. (1: A. djedaba, 2:A. kleinii, 3:A. vari, 4:S. nigrofasciata, 5: T. mookalee and 6: U. helvola).(L:100 bp ladder). 


\section{DISCUSSION}

The present study showed a new record of $U$. helvola in the Iraqi marine waters for the first time. Although it known from the Arabian Gulf, but the environment of Iraqi marine waters are quite different in compare with the remaining parts of the Arabian Gulf. The Iraqi marine waters affects by freshwater of the Shatt Al-Arab River, which is formed by the confluence of Euphrates and Tigris rivers, in addition to Karun River. The Shatt Al-Arab River and its associated marshes present potential sources of nutrients, organics and pollutants [9].

Meristic and morphometric characteristics of $U$. helvola were agreement with the results of [4] and [3] when they showed that $U$. helvola could be characterized by body oblong and compressed, dorsal profile strongly convex, ventral profile slightly convex to isthmus, total gill rakers range from 19 to 24 , two dorsal fins, the first with eight short slender spines followed by 25 to 30 soft rays, anal fin with two detached spines (embedded and not apparent in all but very young) followed by 19 to 22 soft rays, pectoral fin falcate, reaching to beyond function of straight and curved lateral line in bigger specimens pelvic fins very long in young but becoming relatively shorter with age.

Carangid fish are noted for the changes they undergo with growth, and these changes have likely been responsible for misidentification of specimens and contributed to some of the general taxonomic confusion that has occurred. In the case of $U$. helvola, fish below $150 \mathrm{~mm}$ SL possess both anterior and posterior retrosescutes and middle antrosescutes, but in larger fish the antrosescutes have gradually transformed and only retrosescutes are present [10]. [11] recognized two species of Uraspis and distinguished them as follows:

1- a: Pelvic always longer than half length of pectoral, some teeth distinctly and strongly curved, some scute points antrose with age ...... U. uraspis.

1- b: Pelvic shorter than half length of pectoral, teeth erect, hardly recurved, scute points retrose ..... U. helvola.

But [12] Reuben (1968) shows that all the characters used by [11] to distinguish the two species can be seen in the same individual at different stages of growth. Furthermore, it is also found during her study of $U$. helvola that some specimens with pelvic fins less than half length of pectoral fins have a few scutes reversed.

The analysis of RAPD results has found a wide range of applications in gene mapping, population genetics and molecular evolutionary genetics. Thus could be attributed to their efficiency in generating large numbers of markers in a short period [13]. The fingerprinting technique is important since it is relatively easy to obtain valuable data, reliable and simple to set up [14]. DNA fingerprinting of $U$. helvola and five species of carangid fish revealed a genetic variation between them which were evident by the number and size of amplified bands. Obtained results are in accordance with the results of [15], when they proved the genetic variation between two hybrids of carangid fishes of the genus Caranx employing same primers. RAPD technique was successfully used to detect the genetic variation between different fish species. [16] used PCR-RAPD technique with seven decamere primers to identify eight cyprinid fish species from Shatt Al-Arab River, southern Iraq. [17] evaluates common patterns of genetic variations among two species of carangid fish in Iraq using the same technique. It can be concluded that our results proved the reliability and viability based on morphological features and molecular technique to identify $U$. helvolaas new records in the marine waters of Iraq.

\section{CONCLUSION}

This study revealed the present of the white tongue jack, Uraspis helvola (Forster, 1801) for the first time in the Iraqi marine waters, northwest Arabian Gulf.

\section{REFERENCES}

[1] Eschmeyer WN, Fong JD, "Species by family/subfamily in the Catalog of Fishes ", California Academy of Sciences. www.calacademy.org (15 Feb. 2015), 2015.

[2] Smith-Vaniz WF, "Carangidae". In: W. Fischer, W. and G. Bianchi, G. (Eds). FAO species identification sheets for fishery purposes. Western Indian Ocean Fishing Area 51. vol. 1. FAO, Rome, 1984.

[3] Yeo, Kim "New record of Uraspis uraspis and re-description of Uraspis helvola (Pisces: Carangidae) from Korea", Korean Journal of Ichthyology, vol. 28, no. 1, pp. 57-64, 2016.

[4] Carpenter KE, Niem VH, "FAO species identification guide for fishery purposes. The living marine resources of the Western Central Pacific. vol. 4. Bony fishes part 2 (Mugilidae to Carangidae). Rome, FAO., pp: 2069-2790, 1999.

[5] Assadi H, Dehgani RP, “Atlas of the Persian Gulf \& the Sea of Oman Fishes”, Iranian Fisheries Research and Training Organization, p. 226, 1997. 
[6] Carpenter KE, Krupp F, Jones DA, Zajonz, U, "FAO species identification guide for fishery purposes", The living marine resources of Kuwait, Eastern Saudi Arabia, Bahrain, Qatar, and the United Arab Emirates. Rome, FAO. pp. 293, 1997.

[7] Bishop JM, "History and current checklist of Kuwait's Ichthyofauna. Journal of Arid Environments, vol. 54, pp. 237256, 2003

[8] Nei M, Li WS, "Mathematical model for studying genetic variation in terms of restriction endonucleases", In Proceedings of the National Academy of Sciences of the United States of America. 76, pp. 5269-5273, 1979.

[9] Al-Yamani FY, "Importance of the freshwater influx from the Shatt-Al-Arab River on the Gulf marine environment". In: Abuzinada, A.H., Barth, H., Krupp, F., Böer, B. and Abdessalaam, T.Z. (Eds), Protecting the Gulf's Marine Ecosystems from Pollution. Birkhäuser Verlag AG, P.O. Box 133, CH-4010 Basel, Switzerland, pp. 207-222, 2008.

[10] Honebrink RR, "A review of the biology of the family Carangidae, with emphasis on species found in Hawaiian waters", DAR Technical Report 20-01. Division of Aquatic Resources, Honolulu, Hawaii 96813, 2000.

[11] Smith JLB, "The rare ' Furred Tongue' Uraspis uraspis (Gnnther), from south Africa and other new records from there", Ichthyological Bulletin, vol. 26, pp. 505-308, 1962.

[12] Reuben S, "Uraspis helvola (Forster) (Carangidae: Pisces) a detailed description with remarks on the species of the genus Uraspis Bleker", Journal of the Marine Biological Association of India, vol. 10, no. 1, pp. 133-151, 1968.

[13] Bardakci F, "Random Amplified Polymorphic DNA (RAPD) Markers", Turkish Journal of Biology, vol. 25, pp. 185-196, 2001.

[14] Shifat R, Begum A, Khan H, "Use of RAPD fingerprinting for discriminating two populations of Hilsa shad (Tenualosa ilisha Ham.) from inland rivers of Bangladesh", Journal of biochemistry and molecular biology, vol. 36. No. 5. pp. 462-467, 2003.

[15] Murakami K, James SA, Randall JE, Suzumoto AY. "Two hybrids of Carangid fishes of the genus Caranx, $C$. ignobilis x C. melampygus and C. melampygus x C. sexfasciatus, from the Hawaiian islands", Zoological Studies, vol. 46, no. 2, pp. 186-193, 2007.

[16] Faddagh MS, Hussain NA, Al-Badran AI, "DNA finger printing of eight cyprinid fish species of Iraqi inland waters using RAPD-PCR technique”, Advances in Life Sciences, vol. 2, no. 2, pp. 9-16, 2012.

[17] Al-Faisal AJ, Mohamed AM, Jaayid TA, "New record of the carangid fish from the Iraqi marine waters, northwest Arabian Gulf”, Mesopotamia Environmental Journal, Special Issue (A), pp. 107-114, 2016. 